\title{
18. MINERALOGY AND SULFUR ISOTOPIC COMPOSITION OF THE MIDDLE VALLEY MASSIVE SULFIDE DEPOSIT, NORTHERN JUAN DE FUCA RIDGE ${ }^{1}$
}

\author{
Rowena C. Duckworth, ${ }^{2}$ Anthony E. Fallick, ${ }^{3}$ and David Rickard ${ }^{2}$
}

\begin{abstract}
The Middle Valley deposit is one of the largest massive sulfide deposits so far discovered on the seafloor. It is hosted within a thick $(\sim 500 \mathrm{~m})$ sequence of alternating turbidites and hemipelagic sediments that overlie an equally thick sediment-basaltic sill complex. Pyrite and pyrrhotite are the most common phases within the deposit, with lesser amounts of sphalerite, magnetite, and chalcopyrite. Carbonates, hydrated magnesium silicates, and iron oxyhydroxides are common interstitial phases, and are paragenetically later than the sulfides. Hydrothermal reworking has resulted in some zone refining, with sphalerite enriched near the top of the deposit and chalcopyrite more common at deeper levels within the sulfide mound. Porous areas appear to have become sites for minor element accumulation during this metal redistribution. The deposit appears to have undergone pervasive low-temperature oxidation due to the circulation of a seawater-dominated fluid that has resulted in the oxidation of pyrrhotite to pyrite + magnetite, and the precipitation of magnesium-rich silicates and carbonates in voids between earlier-formed sulfide minerals.

Sulfur isotope values of primary pyrite and pyrrhotite are relatively high, with a maximum value of $9.8 \%$, although there is a wide spread in the data $\left(\delta^{34} \mathrm{~S}=1.3 \%\right.$ to $9.8 \%$ ). These sulfides are isotopically heavier than those from massive sulfide deposits on sediment-free spreading centers, where the sulfur is mainly derived from footwall basalts. The high sulfur isotope values of the Middle Valley sulfides reflect mixing in the hydrothermal fluids of basalt-derived sulfide with reduced seawater sulfate trapped in the porous turbidites.
\end{abstract}

\section{INTRODUCTION}

Middle Valley is a sedimented axial rift valley on the northern Juan de Fuca Ridge, located approximately $150 \mathrm{~km}$ west of Vancouver Island (Fig. 1). The tectonics of the region are described in Davis and Villinger (1992). The area has been hydrothermally active for several thousand years; this aspect was the focus of Ocean Drilling Program (ODP) Leg 139 in the summer of 1991. Samples from the massive sulfide deposit drilled at Site 856 form the basis for this study. Sulfides from this site are unique, as they are the first extensive suite of samples with well-constrained depths recovered from a recent massive sulfide deposit on the seafloor. The vertical aspect of the sample suite is especially important, as it may allow the recognition of postdepositional processes within the sulfide mound.

Two main types of sulfide deposits have been discovered on the seafloor. First are those deposits that precipitated directly onto basalts at spreading ridges and in back-arc basins, such as the East Pacific Rise (Hekinian and Fouquet, 1985), the Mid-Atlantic Ridge (Thompson et al., 1988), the southern Juan de Fuca Ridge (Koski et al., 1984) and the Lau and Okinawa back-arc basins (Fouquet et al., 1991; Halbach et al., 1989). Second are the deposits enclosed within thick sedimentary sequences that cover spreading centers, such as Guaymas Basin and Escanaba Trough (Koski et al., 1985, 1988). The Middle Valley deposit appears at first sight to fit into the latter classification because it is within a thick succession of alternating turbidites and hemipelagic sediments. However, other modern sediment-hosted sulfide deposits show a mineral and elemental diversity that reflects a dominant sedimentary source, which is not seen at Middle Valley (Davis, Mottl, Fisher, et al. 1992). Indeed, the mineralogy and sulfide geochemistry of the Middle Valley deposit are more similar to East Pacific Rise (EPR)-type deposits, suggesting a basaltic source rock for most of the metallic constituents within the deposit.

\footnotetext{
'Mottl, M.J., Davis, E.E., Fisher, A.T, and Slack, J.F. (Eds.), 1994, Proc. ODP. Sci. Results, 139: College Station, TX (Ocean Drilling Program).

${ }^{2}$ Dept. Geology, P.O. Box 914, University of Wales College of Cardiff, Cardiff CFI 3YE, Wales, United Kingdom.

${ }^{3}$ Isotope Geology Unit, Scottish Universities Research and Reactor Center, East Kilbride, Glasgow G75 0QU, Scotland, United Kingdom.
}

The source of the sulfur in seafloor sulfide deposits has been investigated by numerous authors using sulfur isotopes (e.g., Styrt et al., 1981; Zierenberg et al., 1984; Shanks and Seyfried, 1987; Woodruff and Shanks, 1988). $\delta^{34} \mathrm{~S}$ values for the EPR-type sulfides typically lie within a narrow range between about $1 \%$ to $4.5 \%$ (Arnold and Sheppard, 1981; Kerridge et al., 1983; Zierenberg et al., 1984), and are only slightly heavier than magmatic sulfide, which has a $\delta^{34} \mathrm{~S}$ value of about $0 \%$. $\delta^{34} \mathrm{~S}$ values in the range $0 \%$ to $4 \%$ commonly are interpreted as indicating that at least $90 \%$ of the sulfur is from deep-seated basaltic source rocks (Arnold and Sheppard, 1981). Sediment-hosted sulfides, however, show a wider spread of values, which may reflect the incorporation of isotopically lighter, bacterially derived sulfur into the system, e.g., Guaymas Basin, where $\delta^{34} \mathrm{~S}$ values of sulfide minerals range from $-3.7 \%$ to $4.5 \%$ (Peter and Shanks, 1992). These authors interpret such data as indicating that several sources for the sulfur were involved in the formation of the deposits. Similar sediment-hosted massive sulfide deposits in Late Cretaceous to Eocene rocks of southcentral Alaska have a range of $\delta^{34} \mathrm{~S}$ values from $2.7 \%$ to $9.2 \%$ that Crowe et al. (1992) interpret as reflecting increased amounts of inorganically reduced seawater sulfate in the hydrothermal fluid, with sulfate reduction occurring in the seawater-hydrothermal fluid mixing zone below the seawater-sediment interface.

The aim of this study is to describe the mineralogy, textures, and sulfur isotope systematics of the Middle Valley massive sulfide deposit, with a view to characterizing the paragenesis and source of the sulfur, and the postdepositional history of the deposit.

\section{REGIONAL GEOLOGY}

Middle Valley is infilled with approximately $500 \mathrm{~m}$ of alternating turbidites and hemipelagic sediments that are underlain by an equally thick sediment-sill complex. These sills, which are basaltic in composition, vary in thickness to a maximum of about $20 \mathrm{~m}$. Site 856 is located in the eastern part of Middle Valley, approximately $3 \mathrm{~km}$ west of the fault scarp that forms the eastern wall of the valley (Fig. 2). The sulfide mound is $35 \mathrm{~m}$ high and is just south of a large circular hill composed of indurated sediments that have been intruded by picritic sills. These sills are probably younger than the sulfide mound to the south, and their intrusion may have caused the uplift of this hill. These 


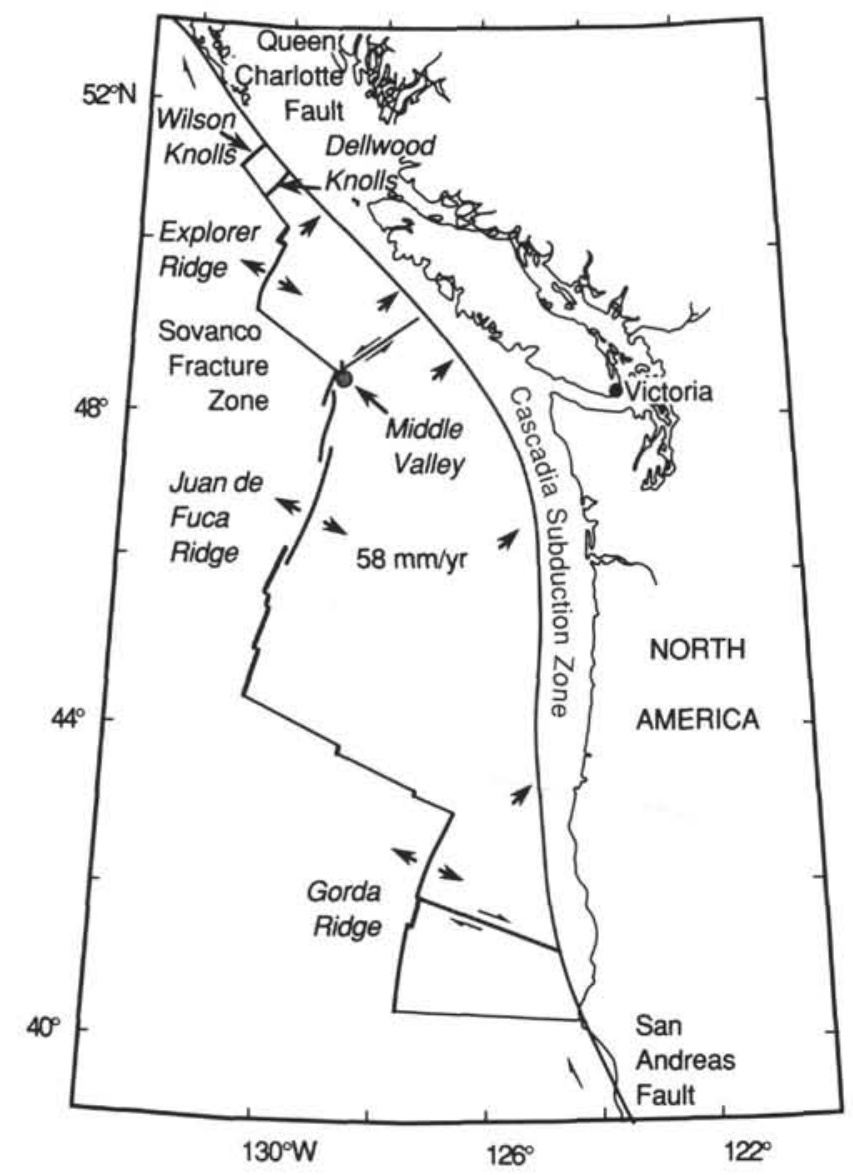

Figure 1. Location of Middle Valley off the west coast of North America. Arrows indicate plate movement.

geochemically primitive picritic sills are also younger than the basaltic sills that form part of the regional sediment-sill complex (Davis, Mottl, Fisher, et al., 1992). The geography and geology of the study area is illustrated in Figure 3, including an active vent site to the south of the sulfide mound that is presently discharging clear, hot fluid at a temperature of $264^{\circ} \mathrm{C}$. This area was not investigated during Leg 139.

An array of six holes was drilled through the sulfide mound, but only two of these, $856 \mathrm{H}$ and $856 \mathrm{G}$, penetrated it successfully. Samples from Holes $856 \mathrm{D}, 856 \mathrm{G}$, and $856 \mathrm{H}$, which are a maximum of about $50 \mathrm{~m}$ apart, have been analyzed in this study. Holes $856 \mathrm{G}$ and $856 \mathrm{H}$ are only about $10 \mathrm{~m}$ apart. Hole $856 \mathrm{H}$ was drilled to a total depth of $94 \mathrm{~m}$ below seafloor ( $\mathrm{mbsf}$ ) before the hole was blocked by heavy sulfide rubble and could not be cleared. At this depth massive sulfide was still recovered, so the true thickness of the deposit is not known, nor is the nature of the footwall beneath it. However, from the recovered material and from geochemical and resistivity wireline logging, it is clear that the mound is uniformly composed of sulfide material, without major intercalated sedimentary layers.

Site 858 is northwest of Site 856 (Fig. 2) and is an area of high heat flow and hydrothermal venting. Fluids at Site 858 are actively discharging on the seafloor at temperatures of $276^{\circ} \mathrm{C}$ (Davis, Mottl, Fisher, et al., 1992). Although no massive sulfide deposit has been found at this site, some sulfide mineralization in the form of veins and laminae occurs in chloritized sediments. Sulfur isotope measurements have been made on samples from Site 858 to compare with the massive mineralization at Site 856. However, these hydrothermal systems are temporally unrelated; the sulfides at Site 856 are believed to be at least $10,000 \mathrm{yr}$ old (Davis, Mottl, Fisher, et al., 1992) and are a product of a fossil hydrothermal event, whereas Site 858 is currently active.

\section{ANALYTICAL PROCEDURES}

Samples obtained during Leg 139 were studied using reflected and transmitted light microscopy and scanning electron microscope (SEM) imaging, and were geochemically investigated by semiquantitative SEM energy-dispersive and wavelength-dispersive spectrometry (EDS, WDS), and by sulfur isotopic analyses of mineral separates.

For the sulfur isotopic analyses the mineral separates were obtained by precision drilling and hand picking under a binocular microscope. The purity of the prepared samples was checked using X-ray diffractometry (XRD). Analyses were done at the Isotope Geology Unit at the Scottish Universities Research and Reactor Center, East Kilbride, Scotland. The sulfide separates were thermally decomposed with a mixture of $\mathrm{Cu}_{2} \mathrm{O}$ at $1076^{\circ} \mathrm{C}$, following the method of Robinson and Kusakabe (1975). $\mathrm{SO}_{2}$ was extracted, cryogenically purified, and analyzed on a VG SIRA II triple-collector mass spectrometer. The results are given in conventional $\delta^{34} \mathrm{~S}$ notation relative to the Canyon Diablo troilite standard. The precision of the data is $\pm 0.2 \%$.

\section{MINERALOGY AND TEXTURES}

The Middle Valley sulfide deposit is a pyrite-pyrrhotite body with low grades of zinc and copper occurring as sphalerite and chalcopyrite, respectively. On a meso-scale, the outstanding feature is the heterogeneity of the samples recovered. No layering was observed, and individual samples show complex paragenetic relations and sharp mineralogic and chemical contacts.

Apart from pyrrhotite, pyrite, sphalerite, and chalcopyrite, the other common minerals are magnetite, talc, $\mathrm{Mg} / \mathrm{Fe}$-carbonates, barite, marcasite, hematite, iron oxyhydroxides, quartz, chlorite, anhydrite, and amorphous silica. Cassiterite, a ( $\mathrm{Bi}, \mathrm{Ag}, \mathrm{Pb})$ sulfide phase, and a $\left(\mathrm{U}, \mathrm{P}_{2} \mathrm{O}_{5}, \mathrm{Si}\right)$ phase also occur as minor constituents.

\section{Pyrrhotite}

Pyrrhotite forms between $30 \%-90 \%$ by volume of the individual samples, and appears to be a primary mineral in all sections studied. It is not yet known whether the pyrrhotite is hexagonal or monoclinic. At surface levels it occurs as interlocking laths that form a typical boxwork texture (Pl. 1, Fig. 1). These are commonly overgrown by pyrite or have thin $(10 \mu \mathrm{m})$ pyrite rims (Pl. 1, Fig. 2). The pyrrhotite laths may also have been subjected to dissolution processes as they have hollow centers in which some pyrite euhedra have crystallized (Pl. 1, Fig. 3). In samples from deeper levels within the deposit, coarser-grained pyrrhotite is associated with sphalerite and chalcopyrite (Pl. 1, Fig. 4). However, pyrrhotite in all parts of the deposit has been affected to some extent by oxidation to pyrite and magnetite. In many samples it shows signs of alteration (Pl. 2, Fig. 1), and the alteration product is chemically between pyrrhotite and pyrite. This intermediate product has more sulfur than pyrrhotite, but not quite as much as pyrite. A typical EDS chemical analysis for this oxidation product is $\mathrm{S}=48.7 \%, \mathrm{Fe}=$ $48.9 \%$ ( $+0.3 \% \mathrm{Mg}$ and $+0.5 \% \mathrm{Si}$ ), equivalent to $\mathrm{FeS}_{1.74}$ or $\mathrm{Fe}_{0.58} \mathrm{~S}$.

\section{Pyrite}

Pyrite is a ubiquitous mineral that can form up to $90 \%$ of a sample. It occurs as primary and secondary phases. Primary pyrite is either colloform (Pl. 2, Fig. 2), euhedral, or in massive fine-grained aggregates. Skeletal crystals also appear to be a primary texture. Secondary pyrite forms massive aggregates with relict pyrrhotite inclusions, idiomorphic crystals or as a pseudomorphic replacement of pyrrhotite laths. EDS probes of random pyrite grains, both primary and secondary, from all parts of the deposit, showed that none of the pyrite contains any significant concentrations of trace elements.

Relatively common "holey" pyrite (Pl. 2, Fig. 3) may be a product of oxidative dissolution of primary pyrrhotite (cf. Murowchick, 1992). 


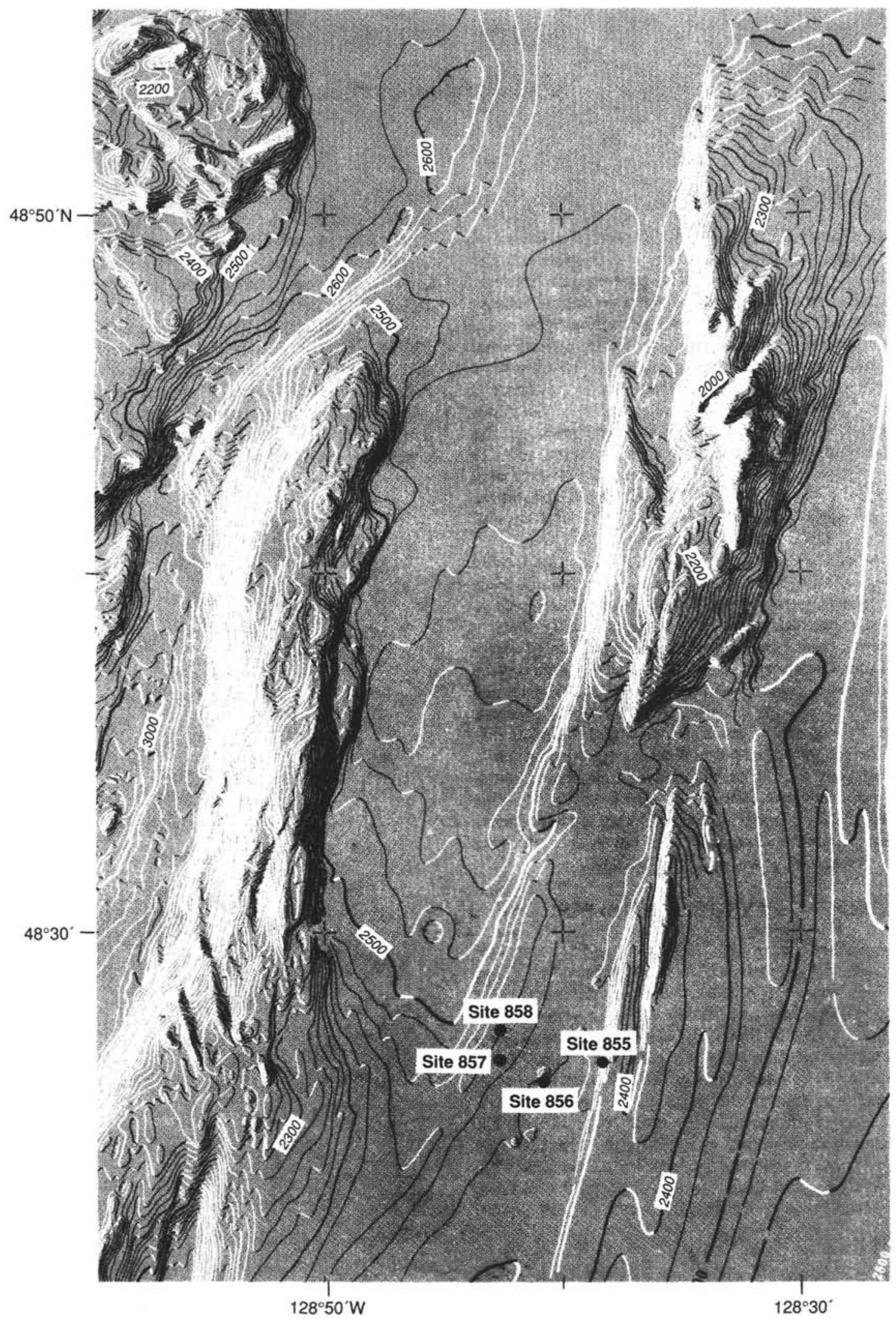

Figure 2. Bathymetry of Middle Valley showing Leg 139 site locations. Contours drawn at 20-m intervals. 


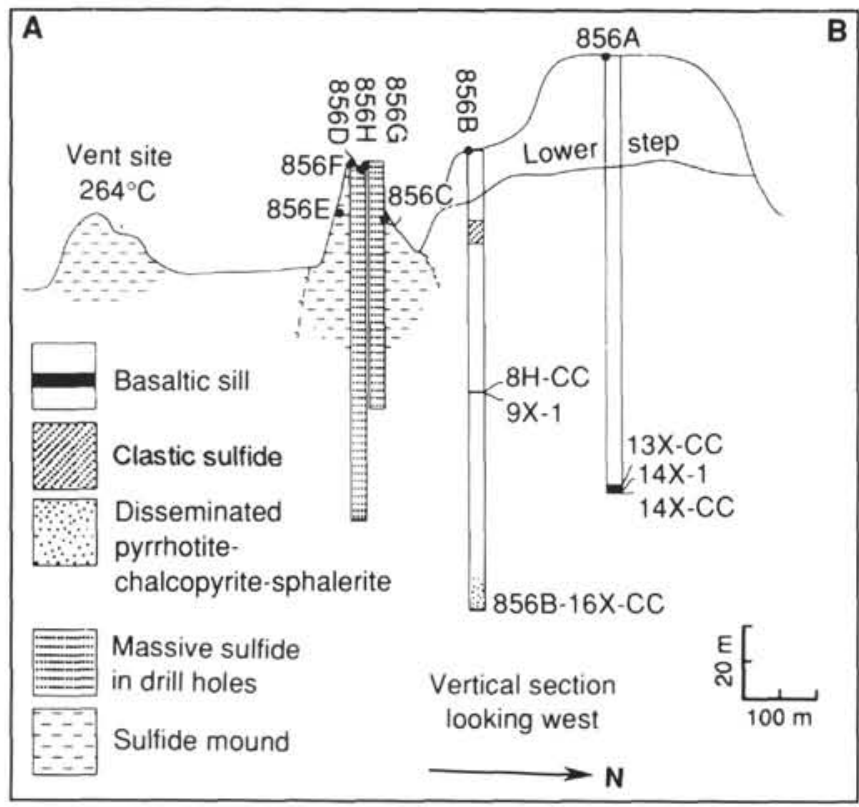

Figure 3. South-north cross section of Site 856 showing drilled holes and the massive sulfide mound. Vertical scale is at $\times 5$ exaggeration.

The numerous pore spaces within the pyrite are typically infilled by $\mathrm{Fe}, \mathrm{Mg}, \mathrm{Al}$ silicates. The continued oxidation of pyrrhotite produces the assemblage pyrite + magnetite, which is more frequently observed than the porous pyrite. The pyrite + magnetite assemblage commonly produces an emulsion-like texture (PI. 2, Fig. 4).

\section{Magnetite}

Magnetite coprecipitates with pyrite as a result of the oxidation of pyrrhotite. It also may replace primary marcasite: common radial magnetite spheroids may be pseudomorphs of primary marcasite structures (Pl. 3, Fig. 1). There appears to be a complex paragenesis of the magnetite, pyrite, and magnetite-pyrite emulsions as shown in Plate 3, Figure 2. Marcasite spheroids, now replaced by magnetite, were overgrown and partially replaced by pyrrhotite. The pyrrhotite was then totally replaced by pyrite and by a pyrite-magnetite emulsion (crystallographically controlled?) which overprinted the magnetite spheroids. The magnetite spheroids finally were oxidized to hematite and then to iron oxyhydroxides. This sequence of oxidation of magnetite is common in the Middle Valley samples. However, there is no vertical trend in the degree of oxidation through the deposit.

\section{Marcasite}

Marcasite is commonly visible as small inclusions $(10-50 \mu \mathrm{m})$ within pyrite, where the marcasite has been almost completely replaced by the pyrite. In some sections marcasite has nucleated on pyrrhotite grain boundaries and grown euhedrally into voids that are now infilled with iron oxyhydroxides. In most thin sections marcasite is only a minor phase, but it is abundant in a few samples. Much of the original metastable marcasite apparently was converted to more stable iron minerals. Both Goodfellow and Blaise (1988) and Davis et al. (1987) reported marcasite in surficial sulfide samples recovered from earlier cruises in the area. It has also been identified in our samples by X-ray diffraction.

\section{Amorphous Iron Sulfates}

Fractures and growth zones within pyrite grains are commonly infilled by a moderately anisotropic opaque phase. SEM analysis of this phase reveals that it is composed of $\mathrm{Fe}, \mathrm{S}$, and $\mathrm{O}$, suggesting an amorphous hydrated iron sulfate.

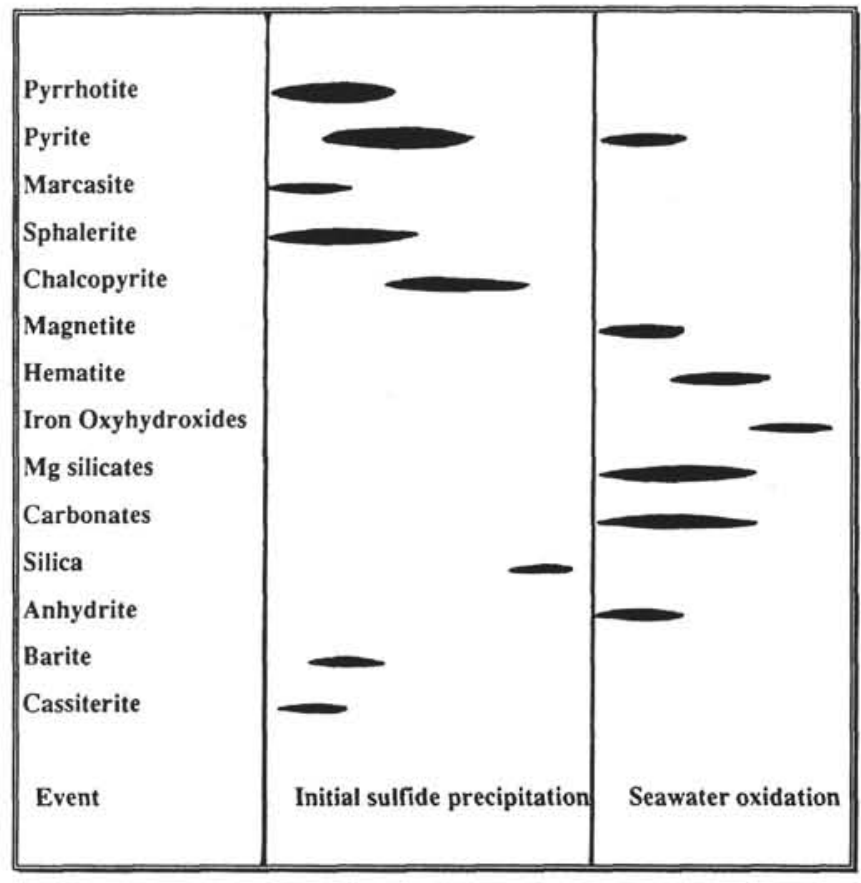

Figure 4. Generalized paragenetic sequence of mineralization in the Middle Valley massive sulfide deposit.

\section{Sphalerite}

Sphalerite is associated particularly with pyrrhotite and increases in abundance in the upper levels of the deposit. The iron content is highly variable, from 2 to 20 atomic percent $\mathrm{Fe}$. The low-iron sphalerite is translucent and occurs predominantly at a depth of about $60 \mathrm{mbsf}$, which is within a zone of massive colloform and porous pyrite. This sphalerite is associated with small $(10-50 \mu \mathrm{m})$ grains of cassiterite, but because both of these minerals are yellowish-brown in transmitted polarized light it is difficult to distinguish them optically. As in many unmetamorphosed sulfide deposits, the Fe content of sphalerite varies considerably even from grain to grain in the same sample. This is consistent with disequilibrium, nonbuffered precipitation under fluctuating physico-chemical conditions.

Sphalerite also varies from "healthy" to intensely "diseased" with chalcopyrite inclusions (Barton and Bethke, 1987), depending on the iron content. The relationship between the iron content and the extent of the chalcopyrite disease is obvious in some sections (Pl. 3, Fig. 3) where, if viewed through transmitted light, the dark Fe-rich zones can be seen to exactly coincide with chalcopyrite-diseased areas. However, some of the totally opaque, highly Fe-rich sphalerites do not seem to be so diseased. Some sphalerite grains exhibit zoning of chalcopyrite around original grain boundaries that developed as the zinc sulfide crystal grew (Pl. 3, Fig. 4).

Sphalerite is commonly replaced by secondary pyrite, which also cuts across the sphalerite as veinlets (Pl. 4, Fig. 1); locally, this pyrite is associated with chalcopyrite. The sphalerite may also contain pyrrhotite inclusions, which seem to be replaced by the sphalerite.

\section{Chalcopyrite}

Chalcopyrite coprecipitates with and replaces sphalerite and also replaces primary pyrrhotite. In one sample, a relict pyrrhotite inclusion in sphalerite is partially replaced by chalcopyrite, which indicates that the paragenetic sequence in this example is pyrrhotite-sphaleritechalcopyrite. Chalcopyrite generally appears to have coprecipitated with secondary pyrite. The chalcopyrite occurs sporadically and cop- 
per grades of the deposit are low, only about $0.2 \%-0.9 \%$ (Davis, Mottl, Fisher, et al., 1992). However, chalcopyrite is more abundant in the deeper levels of the deposit. This is the opposite of the observed distribution of sphalerite, suggesting that some degree of zone refining (e.g., Eldridge et al., 1983) has taken place.

\section{$\mathrm{Mg}(\mathrm{Fe})$ Silicates}

Magnesium-rich silicates are ubiquitous throughout the deposit. Two distinct phases, talc and serpentine, have been identified by optical and XRD methods. In transmitted light the talc is colorless and typically fibrous, with high birefringence (Pl. 4, Fig. 2). Serpentine is less common than talc and is generally mottled, with the more hydrated areas forming circular patches. It occurs mainly as massive aggregates of fibrous material. Although both minerals are hydrated magnesium silicates, in Middle Valley they also typically contain some iron (up to $12 \mathrm{wt} \% \mathrm{FeO}$ ). The iron-bearing talc is similar to that reported from hydrothermal deposits in the Guaymas Basin (Lonsdale et al., 1980; Koski et al., 1985). However, it lacks aluminium and sodium. The only aluminium-bearing phases found in any of the samples are chlorite and the $\mathrm{Fe}, \mathrm{Mg}, \mathrm{Al}$ silicates that infill the porous pyrite. The magnesium silicates occur as primary precipitates and infill voids between the earlier formed sulfide minerals. Plate 4, Figure 3, shows magnesium silicates infilling the cores of colloform pyrite structures.

\section{Carbonates}

$\mathrm{Mg}, \mathrm{Fe}( \pm \mathrm{Ca})$ carbonates are a common interstitial phase in the massive sulfide deposit. Carbonates occur throughout the deposit, but are especially abundant in the surficial samples where they form the cement to friable sulfide material. Dolomite is common, as are carbonates having compositional variations in the solid solution series between siderite and magnesite; some pure calcite has been identified by $\mathrm{XRD}$. The carbonates typically are euhedral and zoned, but a few show a colloform morphology (Pl. 4, Fig. 4). The zoning is sharply defined and seems to be solely the result of iron variations in the mineral (PI. 5, Fig. 1). A typical EDS analysis of an $\mathrm{Mg}, \mathrm{Fe}$-zoned carbonate shows that the iron-rich zones contain siderite with $82.8 \mathrm{wt} \% \mathrm{FeCO}_{3}, 3.8 \mathrm{wt} \%$ $\mathrm{MgCO}_{3}$, and 0.9 wt\% $\mathrm{CaCO}_{3}$, which is equivalent to $\left(\mathrm{Fe}_{0.9} \mathrm{Mg}_{0.1}\right) \mathrm{CO}_{3}$. The zones depleted in iron consist of magnesite-siderite solid solution with 62.3 wt $\% \mathrm{FeCO}_{3}, 26.7$ wt $\% \mathrm{MgCO}_{3}, 6.0$ wt $\% \mathrm{CaCO}_{3}$, and 1.2 wt $\% \mathrm{MnCO}_{3}$, which is equivalent to $\mathrm{FeMg}\left(\mathrm{CO}_{3}\right)_{2}$. Some Fe-rich carbonates are zoned with $\mathrm{Mg}$-carbonate.

Like the $\mathrm{Mg}, \mathrm{Fe}$ silicates, these $\mathrm{Mg}$-rich carbonates have textures that suggest open-space growth and therefore primary precipitation from seawater-dominated fluids circulating through the already-formed sulfide mound.

\section{Silica Phases}

Quartz and amorphous hydrated silica occur locally as interstitial phases. Quartz is more common than the amorphous silica, but some of the quartz may be a relict sedimentary phase. Some quartz is faintly optically zoned. Textural evidence suggests that both these silica phases were precipitated after the sulfide minerals, but before the deposition of the carbonate minerals.

\section{Sulfates}

Both minor barite and anhydrite occur in the Middle Valley deposit, but barite is more common. Barite forms small, 100-500 $\mu \mathrm{m}$, euhedral to subhedral prismatic inclusions in pyrite (Pl. 5, Fig. 2) or silicates. Therefore, the barite must have crystallized before these minerals. Acicular anhydrite grows on the surface of samples, and generally was plucked out during thin section preparation. It is also associated with $\mathrm{Mg}$-silicates, and appears to have coprecipitated with these phases; therefore, the anhydrite is paragenetically later than the barite.

\section{Iron Oxyhydroxides}

Goethite and lepidicrocite are the main hydrated iron oxide phases. They occur interstitially within the massive sulfide, and in transmitted light occur as reddish-yellow amorphous masses.

\section{Cassiterite}

Cassiterite is found as small, $20-50 \mu \mathrm{m}$, euhedral to subhedral grains (Pl. 5, Fig. 3), associated with low-Fe sphalerite. It seems to occur exclusively in massive colloform pyrite from a zone about $60 \mathrm{mbsf}$. In this zone, the cassiterite is evenly distributed throughout the samples.

\section{Minor Phases}

Several unusual phases were found within the massive colloform pyrite zone at $\sim 60$ mbsf using SEM. These phases are rare and exceedingly small. Several grains, approximately 5-10 $\mu \mathrm{m}$ long, of a lead-silver-bismuth sulfide occur around pyrite grains in fractures and voids. Analysis of this phase in wt $\%$ gives $10.1 \% \mathrm{Ag}, 23.3 \% \mathrm{~Pb}$, $42.1 \% \mathrm{Bi}, 13.0 \% \mathrm{~S}, 2.8 \% \mathrm{Fe}$ and $0.3 \% \mathrm{Cu}$, yielding an approximate formula of $(\mathrm{Pb}, \mathrm{Ag})_{4}(\mathrm{Fe}, \mathrm{Cu}) \mathrm{Bi}_{4} \mathrm{~S}_{8}$. It is compositionally similar to sulfosalts that are based on the galenobismuthite formula $\mathrm{PbSBi}_{2} \mathrm{~S}_{3}$.

There is also a uranium mineral in the deposit, as yet unidentified, that again is seen only as tiny grains. This phase contains phosphorous and silica as well as uranium, but is too small for quantitative analysis by SEM.

\section{Paragenetic Sequence}

The mineralogy and mineral textures of the Middle Valley samples suggest that two types of fluid were involved in the formation of the deposit. The first was a high-temperature, low-pH hydrothermal fluid that precipitated the pyrrhotite, sphalerite, cassiterite, barite, chalcopyrite, pyrite, and marcasite. On the scale of a single thin section, complex paragenetic relationships point to a polyphase hydrothermal history. Multiple stages of mineral replacement, dissolution, overgrowth, and reprecipitation are evident, documenting hydrothermal reworking of the sulfide mound.

Mineralogical and textural evidence suggests that the later fluid had a dominant seawater component, possibly with some hydrothermal fluid input to provide silica, and was cooler $\left(\sim 100^{\circ} \mathrm{C}\right)$, with a neutralalkaline $\mathrm{pH}$ and a high oxygen fugacity. This fluid precipitated the anhydrite, $\mathrm{Mg}$-rich carbonates and silicates, and caused the oxidation of primary pyrrhotite to pyrite + magnetite. Oxidation and hydration of the iron oxide minerals probably also resulted from this lowtemperature fluid reworking. The proposed paragenetic sequence for the overall precipitation of the minerals in the deposit is shown in Figure 4.

\section{SULFUR ISOTOPE SYSTEMATICS}

Sulfur isotope systematics of sulfide mineral separates from the massive sulfide deposit at Site 856 and the actively venting Site 858 were investigated in order to characterize and compare the source of the sulfur in the hydrothermal systems.

\section{Site 856}

Twenty-seven mineral separates from sulfides at Site 856 were analyzed, of which 22 were pyrite samples and five were pyrrhotite samples. Most of the pyrite samples separated consisted of primary pyrite but some secondary pyrites were analyzed from more extremely altered samples.

These sulfides have anomalously high sulfur isotopic signatures compared to basalt-hosted sulfide deposits; the range in $\delta^{34} \mathrm{~S}$ at Mid- 
Table 1. Sulfur isotope data for samples from Site 856.

\begin{tabular}{|c|c|c|c|}
\hline $\begin{array}{l}\text { Core, section, } \\
\text { interval }(\mathrm{cm})\end{array}$ & $\begin{array}{l}\text { Depth } \\
\text { (mbsf) }\end{array}$ & $\begin{array}{l}\delta^{34} \mathrm{~S} \\
(\% 0)\end{array}$ & Mineral \\
\hline $856 \mathrm{D}-1 \mathrm{H}-1,75-78$ & 5.2 & 0.75 & Primary pyrite \\
\hline $856 \mathrm{G}-1 \mathrm{R}-2,3-5$ & 1.3 & 1.53 & Primary pyrite \\
\hline $856 \mathrm{D}-1 \mathrm{H}-4,68-70$ & 4.5 & 5.18 & Primary pyrite \\
\hline $856 \mathrm{D}-1 \mathrm{H}-7,15-17$ & 5.7 & 7.58 & Primary pyrite \\
\hline $856 \mathrm{D}-1 \mathrm{H}-7,76-78$ & 4.2 & 8.19 & Primary pyrite \\
\hline $856 \mathrm{H}-2 \mathrm{R}-1,4-6$ & 1.7 & 13.54 & Primary pyrite \\
\hline $856 \mathrm{G}-3 \mathrm{R}-1,129-131$ & 5.2 & 18.89 & Primary pyrite \\
\hline $856 \mathrm{H}-3 \mathrm{R}-1,68-70$ & 6.0 & 22.78 & Secondary pyrite \\
\hline $856 \mathrm{H}-3 \mathrm{R}-3,83-85$ & 5.9 & 25.54 & Secondary pyrite \\
\hline $856 \mathrm{H}-4 \mathrm{R}-1,75-77$ & 7.6 & 27.35 & Primary pyrrhotite \\
\hline $856 \mathrm{H}-4 \mathrm{R}-1,108-110$ & 9.2 & 27.68 & Secondary pyrite \\
\hline $856 \mathrm{H}-4 \mathrm{R}-2,57-59$ & 8.0 & 28.67 & Secondary pyrite \\
\hline $8561-4 R-2,57-59$ & 7.6 & 28.67 & Primary pyrrhotite \\
\hline $856 \mathrm{H}-6 \mathrm{R}-1,32-34$ & 5.7 & 37.72 & Primary pyrrhotite \\
\hline $856 \mathrm{H}-7 \mathrm{R}-1,8-10$ & 8.1 & 43.18 & Primary pyrite \\
\hline $856 \mathrm{H}-7 \mathrm{R}-1,8-10$ & 6.2 & 43.18 & Primary pyrrhotite \\
\hline $856 \mathrm{G}-6 \mathrm{R}-1,78-80$ & 3.6 & 47.08 & Primary pyrite \\
\hline $856 \mathrm{H}-8 \mathrm{R}-1,110-112$ & 5.8 & 49.10 & Primary pyrite \\
\hline $856 \mathrm{H}-9 \mathrm{R}-1,19-20$ & 7.3 & 52.96 & Primary pyrite \\
\hline $856 \mathrm{H}-1 \mathrm{OR}-1,8-10$ & 8.4 & 57.08 & Primary pyrite \\
\hline $856 \mathrm{G}-7 \mathrm{R}-4,6-8$ & 5.7 & 60.16 & Primary pyrite \\
\hline $856 \mathrm{H}-11 \mathrm{R}-1,94-96$ & 4.8 & 62.24 & Primary pyrite \\
\hline $856 \mathrm{H}-13 \mathrm{R}-1,56-57$ & 2.8 & 71.46 & Primary pyrite \\
\hline $856 \mathrm{H}-14 \mathrm{R}-1,57-59$ & 2.5 & 76.27 & Primary pyrite \\
\hline $856 \mathrm{H}-15 \mathrm{R}-\mathrm{I}, 34-37$ & 3.9 & 80.84 & Secondary pyrite \\
\hline $856 \mathrm{H}-16 \mathrm{R}-1,64-66$ & 6.0 & 85.84 & Primary pyrrhotite \\
\hline $856 \mathrm{H}-17 \mathrm{R}-1,2-4$ & 1.6 & 90.12 & Secondary pyrite \\
\hline
\end{tabular}

dle Valley at Site 856 is $1.3 \%$ to $9.2 \%$ (Table 1). These data are in agreement with the results of Goodfellow and Blaise (1988) for surficial samples collected on earlier cruises from this area. Primary pyrrhotite has a mean $\delta^{34} \mathrm{~S}$ of $6.6 \% \pm \pm 0.8 \%$ o $(\mathrm{n}=5)$, whereas pyrite values (including both primary and secondary pyrite) appear to be more variable, ranging between $1 \%$ and $9 \%(\mathrm{n}=22)$. Interestingly, primary pyrite shows a similar range of $\delta^{34} \mathrm{~S}$ values $(1.3 \%$ to $8.1 \%$ ) to the secondary pyrite ( $1.6 \%$ to $9.2 \%$ ). The mean overall $\delta^{34} \mathrm{~S}$ value for the pyrite at this site is $5.1 \% \pm 2.3 \%(n=22)$, and the median is $5.7 \%$.

No overall depth stratigraphy can be seen in the sulfur isotope data (Fig. 5), but there appears to be three depth zones where the primary pyrite $\delta^{34} S$ values cluster. From the drilled base of the deposit to a level of about $60 \mathrm{mbsf}$, the $\delta^{34} \mathrm{~S}_{\text {pyrite }}$ value averages $3.95 \%$; between 60 and approximately $26 \mathrm{mbsf}, \delta^{34} \mathrm{~S}_{\text {pyrite }}$ averages $6.64 \%$, while the top of the deposit has a mean $\delta^{34} \mathrm{~S}$ pyrite value of $3.97 \%$. However, the pyrrhotite $\delta^{34} \mathrm{~S}$ values do not show any variation with depth. The mean pyrite value from 90 mbsf up to $\sim 60 \mathrm{mbsf}$ is relatively low, and is within the range observed in the EPR deposits ( 1 to $4.5 \%$ ), as is the mean $\delta^{34} \mathrm{~S}$ value for the uppermost zone of the deposit. The mean $\delta^{34} \mathrm{~S}$ value from the middle zone is higher; one coexisting primary pyritepyrrhotite pair suggests that isotopic equilibrium between pyrite and pyrrhotite may have been reached (Sample 139-856H-7R-1, 8-10 $\mathrm{cm})$. However, more analyses on coexisting sulfide pairs need to be undertaken to establish this. The limited $\delta^{34} S_{\text {pyrrhotite }}$ values available are relatively homogeneous, and it is presumed that they are original hydrothermal signatures as the mineralogical textures suggest that all of the analyzed pyrrhotite was primary.

\section{Site 858}

Five pyrite samples were analyzed from the active venting site. Lateral correlation was not possible with this sample set. In any case, the holes at Site 858 are not as deep as those at Site 856, and sulfides occur only as veins and rare layers within the sediments at Site 858 .

This data set shows primary pyrite to have $\delta^{34} \mathrm{~S}$ values ranging from $3 \%$ to $9.8 \%$ (Table 2), a spread similar to that shown by the primary pyrite from Site 856 . However, although it appears that the mineralogy, mineral chemistry, and fluid chemistry are different at the two sites, the source of the sulfur may have been the same.
Table 2. Sulfur isotope data for samples from Site 858.

\begin{tabular}{lccc}
\hline $\begin{array}{c}\text { Core, section, } \\
\text { interval }(\mathrm{cm})\end{array}$ & $\begin{array}{c}\text { Depth } \\
(\mathrm{mbsf})\end{array}$ & $\begin{array}{c}\delta^{34} \mathrm{~S} \\
(\% 0)\end{array}$ & \multicolumn{1}{c}{ Mineral } \\
\hline 858D-2H-2, 114 & 6.1 & 11.90 & Primary pyrite \\
$858 \mathrm{~B}-2 \mathrm{H}-4,91-93$ & 3.6 & 12.61 & Primary pyrite \\
$858 \mathrm{C}-3 \mathrm{H}-4,29-30$ & 9.8 & 17.79 & Primary pyrite \\
$858 \mathrm{C}-5 \mathrm{H}-4,8-10$ & 3.0 & 28.08 & Primary pyrite \\
$858 \mathrm{C}-6 \mathrm{H}-2,43-45$ & 4.2 & 34.93 & Primary pyrite \\
\hline
\end{tabular}

\section{DISCUSSION}

The general paragenetic sequence of the Middle Valley sulfides is pyrrhotite, marcasite, sphalerite, pyrite, and chalcopyrite. This mineralogic assemblage is simple, and the almost total lack of minerals containing more exotic elements such as lead, arsenic, and antimony suggests that the metallic constituents of the massive sulfide deposit were mainly derived from a basaltic source, with little sedimentary input (Koski et al., 1988).

The distribution of sphalerite and chalcopyrite within the deposit suggests that some degree of zone refining (e.g., Eldridge et al., 1983) has taken place during hydrothermal reworking. Trace metals such as tin, lead, and bismuth are all concentrated in the massive colloform pyrite at about $60 \mathrm{mbsf}$, where the initial porosity may have allowed precipitation of these minor phases during the reworking event.

Pervasive low-temperature seawater oxidation has affected all parts of the deposit recovered during drilling on Leg 139. The oxidation has visibly affected a large percentage of the pyrrhotite throughout the deposit, and has either altered it to an intermediate iron sulfide product or completely oxidized it to pyrite + magnetite. Some of the resulting secondary pyrite is porous, with partial infilling of the pores by silicate minerals. The iron in these silicates may have been liberated during the pyrrhotite oxidation reaction (Murowchick, 1992), while the magnesium and aluminium presumably came from seawater (with a suspended particulate component as a source for the aluminium). Precipitation of $\mathrm{Mg}$-rich interstitial carbonates and silicates also resulted from the circulation of cold seawater (as a source for the $\mathrm{Mg}$ ) through the sulfide mound, which was either conductively heated or mixed with late-stage hydrothermal fluids (carrying $\mathrm{Si}$ in solution). This produced a low temperature $\left(100^{\circ} \mathrm{C}\right)$, neutral to alkaline fluid, which substantially modified the mineralogy and texture of the deposit. However, as with the oxidation of the primary pyrrhotite, magnesium phases are found at all levels of the deposit, with no noticeable variations in abundance that would suggest enhanced seawater interaction at particular depths. Therefore, the seawater interaction may have been a steady-state process that occurred throughout the depositional history of the sulfide mound. At present it appears that Leg 139 drilling at Site 856 sampled the massive sulfide deposit at some intermediate stage of oxidation. The degree of this oxidation may be a function of the time it took to form the deposit (i.e., rate of burial) as well as the time elapsed since sulfide formation. The oxidation sequence indicated by the mineralogy is pyrrhotite $\rightarrow$ holey pyrite $\rightarrow$ pyrite + magnetite emulsion $\rightarrow$ magnetite $\rightarrow$ hematite $\rightarrow$ hydrated iron oxides.

This oxidation event does not appear to have significantly affected the sulfur isotope systematics, however, as the data obtained for primary and secondary pyrite are similar. Also, the $\delta^{34} \mathrm{~S}$ data for primary pyrite from the currently active area at Site 858 are similar to those at Site 856.

The iron sulfides at Site 856 have incorporated isotopically heavy sulfur relative to basaltic sulfur values. However, the $\delta^{34}$ S population distribution is essentially unimodal (Fig. 6), suggesting that a simple genetic model may explain the data. The primary pyrrhotite has a relatively homogeneous $\delta^{34} \mathrm{~S}$ value of about $6 \%$; therefore, a source of isotopically heavy sulfur is needed to explain this data. Primary pyrite $\delta^{34} \mathrm{~S}$ values are more heterogeneous and seem to be related to depth in the deposit, and hence to time in the hydrothermal system. 
The source of the isotopically heavy sulfur must be adequate in volume to account for such a large sulfide deposit, especially considering the inefficiency of the precipitation mechanisms. Because the frequency histogram shows an essentially unimodal distribution, this sulfur source must be either a single homogeneous reservoir or several reservoirs that are well mixed. A large, homogeneous, isotopically heavy source of about $6 \%$ is hard to explain; therefore the sulfur probably comes from a well-mixed source. The obvious candidates for this mixed source are seawater sulfate $\left(\delta^{34} \mathrm{~S}=21 \%\right)$ and basaltic sulfide $\left(\delta^{34} S=0 \%\right)$. Seawater trapped in the porous turbiditic sediments could be reduced by hydrothermal fluids that at depth also leach sulfide from basaltic sills in the hydrothermal reaction zone. This mixing of isotopically different sulfur sources could give a $\delta^{34} \mathrm{~S}$ signature of about $6 \%$ for the Middle Valley sulfides, depending on various factors such as efficiency of sulfate reduction, sulfide precipitation temperatures, etc. (e.g., Janecky and Shanks, 1988). The histogram does suggest a slight peak at the lower $\delta^{34} \mathrm{~S}$ values, which may reflect a basaltic sulfide signature and inefficient mixing between these two end members. More data are needed to confirm a bimodal distribution of $\delta^{34} \mathrm{~S}$ values and a possible dual sulfur source.

A large well-mixed sulfur source is consistent with the regional geology, which suggests a path for the hydrothermal fluids through sediments and intercalated basaltic sills. The sediment-sill complex could yield a well-mixed $\delta^{34} \mathrm{~S}$ value of about $6 \%$ through local hightemperature $\mathrm{SO}_{4}^{2-}$ reduction of sediment pore waters by hydrothermal fluids carrying basalt-derived sulfide (as $\mathrm{H}_{2} \mathrm{~S}$ ). This model of inorganic sulfate reduction is analogous to that proposed by Crowe et al. (1992), who reported a similar range of $\delta^{34} S$ values for sedimenthosted massive sulfide deposits of south-central Alaska. This model also explains the similarity in $\delta^{34} \mathrm{~S}$ values of primary pyrite at Sites 856 and 858 .

The simple mineralogy and $\mathrm{Fe}-\mathrm{Cu}$-dominated bulk geochemistry (Davis, Mottl, Fisher, et al., 1992) suggest that the source of the metals was dominantly the basaltic sills. This leaching of basalt would have had an effect on the temperature, $\mathrm{pH}$, and chemistry of the hydrothermal fluids in the reaction zone. The metals were derived dominantly from the sills, whereas the sulfur came from a well-mixed source incorporating reduced seawater sulfate as well as basaltic sulfide.

\section{CONCLUSIONS}

The mineralogy and textures of the Middle Valley sulfides suggest the existence of a former long-lived secondary hydrothermal event characterized by seawater-dominated fluids that produced abundant magnesium silicates and carbonates. At Site 856, two fluid systems formed and modified the sulfide deposit. The first was a typical high-temperature, low-pH, hydrothermal discharge that continued as the mound developed, producing hydrothermal reworking and resultant local zone refining of sphalerite and chalcopyrite in particular. This was followed by a seawater-dominated fluid circulation event with high oxygen fugacity, neutral to alkaline $\mathrm{pH}$, and low temperatures, which resulted in oxidation of the primary pyrrhotite and the precipitation of late-stage $\mathrm{Mg}$-rich silicates and carbonates. Because these Mg-rich minerals are found in all levels of the deposit, and the alteration of pyrrhotite to pyrite + magnetite is also ubiquitous, the circulation of the seawater-dominated fluid must have been either a later long-lived and pervasive event, or continuous during the construction of the sulfide mound.

The $\delta^{34} \mathrm{~S}$ values of the sulfide minerals in the deposit do not appear to have been significantly affected by the seawater-dominated oxidizing event. However, they indicate that the source of the sulfur was isotopically heavy with respect to basaltic sulfide. This may have been caused by almost complete mixing of reduced pore-water sulfate and leached basaltic sulfide as the hydrothermal fluids reacted with the deep-seated sediment-sill complex at Middle Valley.

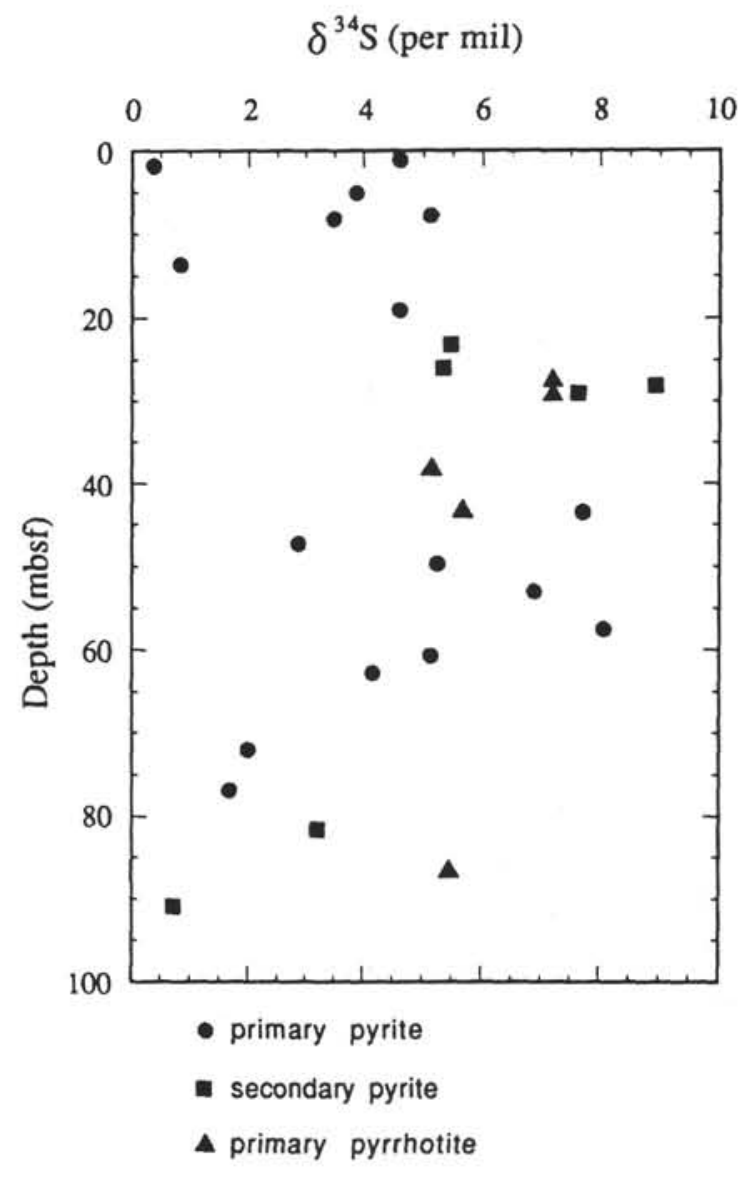

Figure 5. Depth vs. $\delta^{34} \mathrm{~S}$ plot for pyrite and pyrrhotite samples from Site 856 .

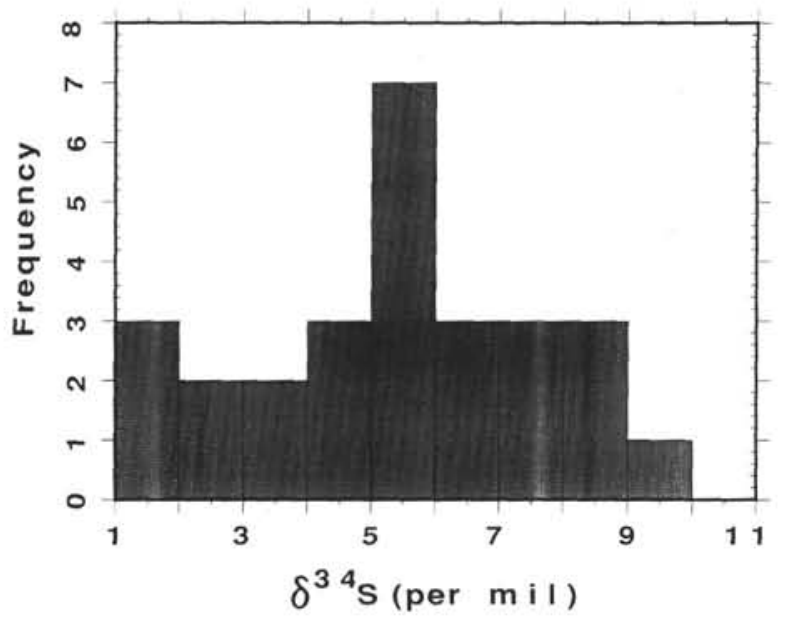

Figure 6. Histogram of $\delta^{34} \mathrm{~S}$ data for Site 856 .

\section{ACKNOWLEDGMENTS}

This study was funded as part of a U.K. Natural Environment Research Council (NERC) Research Fellowship to R.C.D. The Isotope Geology Unit at Scottish Universities Research and Reactor Center is supported by NERC and the Consortium of Scottish Universities. The manuscript was improved by the constructive reviews of John F. Slack, Douglas E. Crowe, and an anonymous ODP referee. 


\section{REFERENCES}

Arnold, M., and Sheppard, S.M.F., 1981. East Pacific Rise at latitude $21^{\circ} \mathrm{N}$ isotopic composition and origin of the hydrothermal sulfur. Earth Planet. Sci. Lett. 56:148-156.

Barton, P.B., Jr., and Bethke, P.M., 1987. Chalcopyrite disease in sphalerite: pathology and epidemiology. Am. Mineral., 72:451-467.

Crowe, D.E., Nelson, S.W., Brown, P.E., Shanks, W.C., III, and Valley, J.W., 1992. Geology and geochemistry of volcanogenic massive sulfide deposits and related igneous rocks, Prince William Sound, south-central Alaska. Econ. Geol., 87:1722-1746.

Davis, E.E., Goodfellow, W.D., Bornhold, B.D., Adshead, J., Blaise, B., Villinger, H., and Le Cheminant, G.M., 1987. Massive sulfides in a sedimented rift valley, northern Juan de Fuca Ridge. Earth Planet. Sci. Lett. $82: 49-61$.

Davis, E.E., Mottl, M.J., Fisher, A.T., et al., 1992. Proc. ODP, Init. Repts., 139: College Station, TX (Ocean Drilling Program).

Davis, E.E., and Villinger, H., 1992. Tectonic and thermal structure of the Middle Valley sedimented rift, northern Juan de Fuca Ridge. In Davis, E.E., Mottl, M.J., Fisher, A.T., et al., Proc. ODP, Init. Repts., 139: College Station, TX (Ocean Drilling Program), 9-41.

Eldridge, C.S., Barton, P.B., Jr., and Ohmoto, H., 1983. Mineral textures and their bearing on formation of the Kuroko orebodies. Econ. Geol. Monogr. 5:241-281.

Fouquet, Y., von Stackelberg, U., Charlou, J.L., Donval, J.P., Foucher, J.P., Erzinger, J., Herzig, P., Mühe, R., Wiedicke, M., Soakai, S., and Whitechurch, H., 1991. Hydrothermal activity in the Lau back-arc basin: sulfides and water chemistry. Geology, 19:303-306.

Goodfellow, W.D., and Blaise, B., 1988. Sulfide formation and hydrothermal alteration of hemipelagic sediment in Middle Valley, northern Juan de Fuca Ridge. Can. Mineral., 26:675-696.

Halbach, P., Nakamura, K., Washner, M., Lange, J., Sakai, H., Kaselitz, L. Hansen, R.D., Yamano, M., Post, J., Prause, B., Seifert, R., Michaelis, W. Teichmann, F., Kinoshita, M., Marten, A., Ishibashi, J., Czerwinski, S., and Blum, N., 1989. Probable modern analogue of Kuroko-type massive sulfide deposits in the Okinawa Trough back-arc basin. Nature, 338:496499.

Hekinian, R., and Fouquet, Y., 1985. Volcanism and metallogenesis of axial and off-axial structures on the East Pacific Rise near $13^{\circ} \mathrm{N}$. Econ. Geol., $80: 221-249$.

Janecky, D.R., and Shanks, W.C., III, 1988. Computational modeling of chemical and sulfur isotopic reaction processes in seafloor hydrothermal systems: chimneys, massive sulfides, and subjacent alteration zones. Can. Mineral., 26:805-825.

Kerridge, J., Haymon, R.M., and Kastner, M., 1983. Sulfur isotope systematics at the $21^{\circ} \mathrm{N}$ site, East Pacific Rise. Earth Planet. Sci. Lett., 66:91-100.

Koski, R.A., Clague, D.A., and Oudin, E., 1984. Mineralogy and chemistry of massive sulfide deposits from the Juan de Fuca Ridge. Geol. Soc. Am. Bull., 95:930-945.
Koski, R.A., Lonsdale, P.F., Shanks, W.C., Berndt, M.E., and Howe, S.S. 1985. Mineralogy and geochemistry of a sediment hosted hydrothermal sulfide deposit from the southern trough of Guaymas basin, Gulf of California. J. Geophys. Res., 90:6695-6707.

Koski, R.A., Shanks, W.C., III, Bohrson, W.A., and Oscarson, R.L., 1988. The composition of massive sulfide deposits from the sediment-covered floor of Escanaba Trough, Gorda Ridge: implications for depositional processes. Can. Mineral., 26:655-673.

Lonsdale, P.F., Bishoff, J.L., Burns, V.M., Kastner, M., and Sweeney, R.E., 1980. A high-temperature hydrothermal deposit on the seabed at a Gulf of California spreading center. Earth Planet. Sci. Lett., 49:8-20.

Murowchick, J.B., 1992. Marcasite inversion and the petrographic determination of pyrite ancestry. Econ. Geol., 87:1141-1152.

Peter, J.M., and Shanks, W.C., III, 1992. Sulfur, carbon, and oxygen isotope variations in submarine hydrothermal deposits of Guaymas Basin, Gulf of California. Geochim. Cosmochim. Acta, 56:2025-2040.

Robinson, B.W., and Kusakabe, M., 1975. Quantitative preparation of $\mathrm{SO}_{2}$ for $34 \mathrm{~S} / 32 \mathrm{~S}$ analysis from sulfides by combustion with cuprous oxide. Anal. Chem., 47:1179-1181.

Shanks, W.C., III, and Seyfried, W.E., Jr., 1987. Stable isotope studies of vent fluids and chimney minerals, southern Juan de Fuca Ridge: sodium metasomatism and seawater sulfate reduction. J. Geophys. Res., 92:1138711399.

Styrt, M.M., Brackmann, A.J., Holland, H.D., Clark, B., Pisutha-Arnond, Eldridge, C.S., and Ohmoto, H., 1981. The mineralogy and isotopic composition of sulfur in hydrothermal sulfide/sulfate deposits on the East Pacific Rise, $21^{\circ} \mathrm{N}$ latitude. Earth Planet. Sci. Lett., 53:382-390.

Thompson, G., Humphris, S.E., Schroeder, B., Sulanowska, M., and Rona, P.A., 1988. Active vents and massive sulfides at $26^{\circ} \mathrm{N}$ (TAG) and $23^{\circ} \mathrm{N}$ (SNAKEPIT) on the Mid-Atlantic Ridge. Can. Mineral., 26:697-711.

Woodruff, L.G., and Shanks, W.C., 1988. Sulfur isotope study of chimney minerals and hydrothermal fluids from $21^{\circ} \mathrm{N}$, East Pacific Rise: hydrothermal sulfur sources and disequilibrium sulfate reduction. J. Geophys. Res., 93:4562-4572.

Zierenberg, R., Shanks, W.C., and Bischoff, J., 1984. Massive sulfide deposits at $21^{\circ} \mathrm{N}$ EPR: chemical composition, stable isotopes, and phase equilibria Geol. Soc. Am. Bull., 95:922-929.

\footnotetext{
- Abbreviations for names of organizations and publications in ODP reference lists follow the style given in Chemical Abstracts Service Source Index (published by American Chemical Society).
}

Date of initial receipt: 2 December 1992

Date of acceptance: 15 June 1993

Ms 139SR-228 


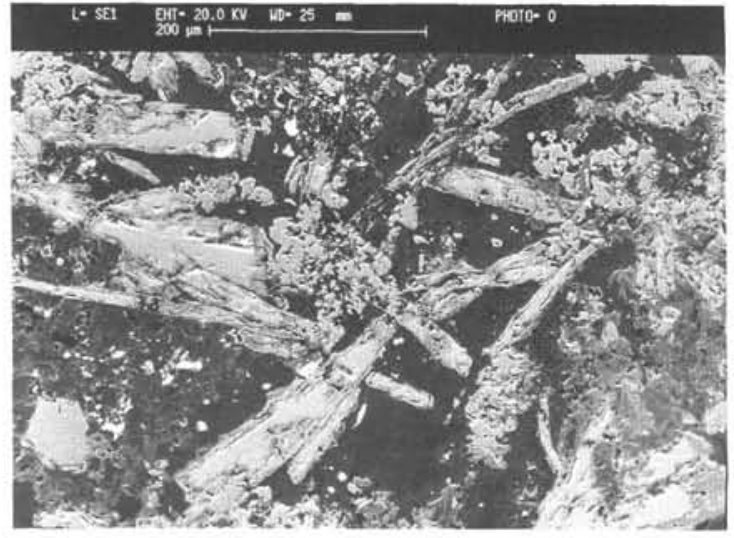

1

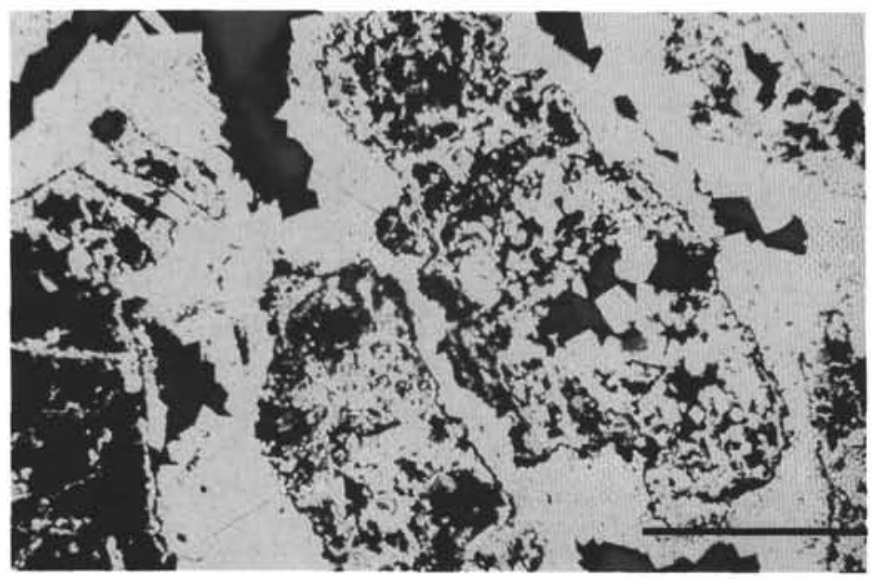

3

Plate 1. 1. SEM photomicrograph of interlocking pyrrhotite laths. 2. SEM photomicrograph showing zoned pyrite rim around pyrrhotite grain. 3. Reflectedlight photomicrograph of partially dissolved pyrrhotite overgrown by pyrite prior to dissolution, and infilled with pyrite euhedra after dissolution. Scale bar $=500$ $\mu \mathrm{m}$. 4. Coarse-grained pyrrhotite associated with sphalerite (dark gray) and interstitial chalcopyrite. Scale bar $=500 \mu \mathrm{m}$.

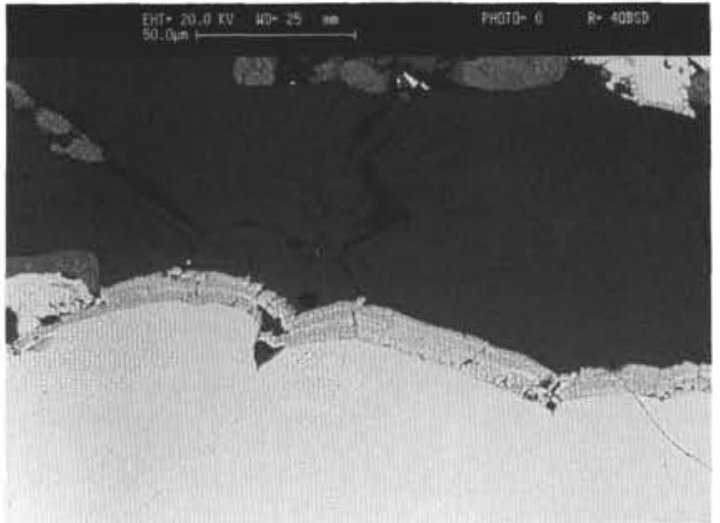

2

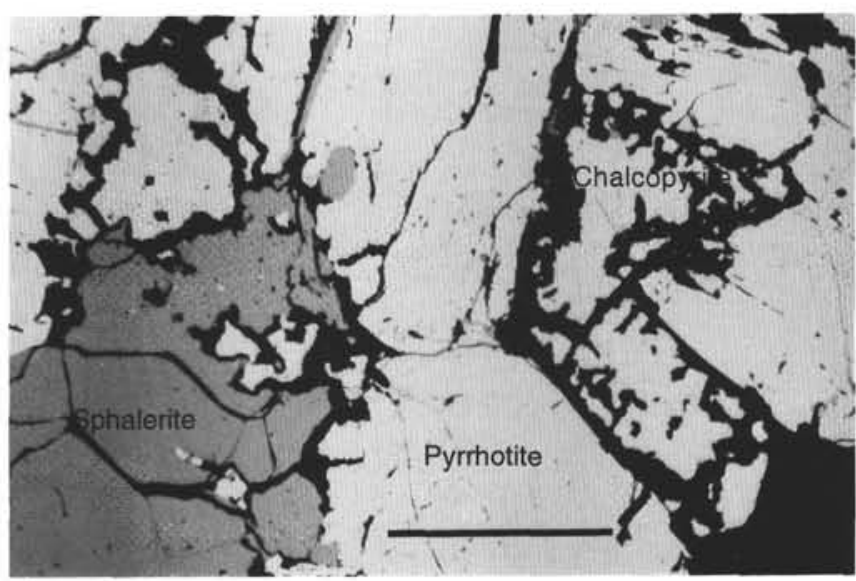

4 


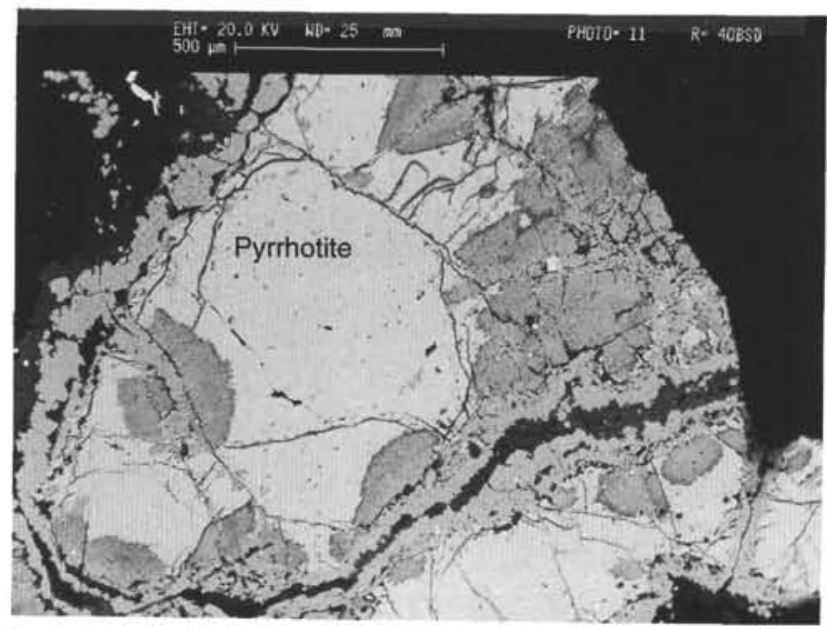

1

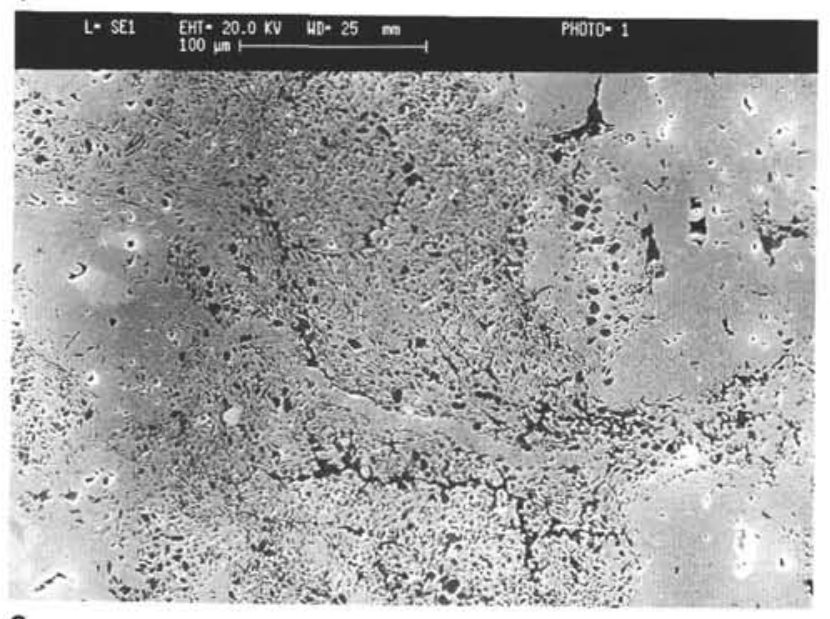

3

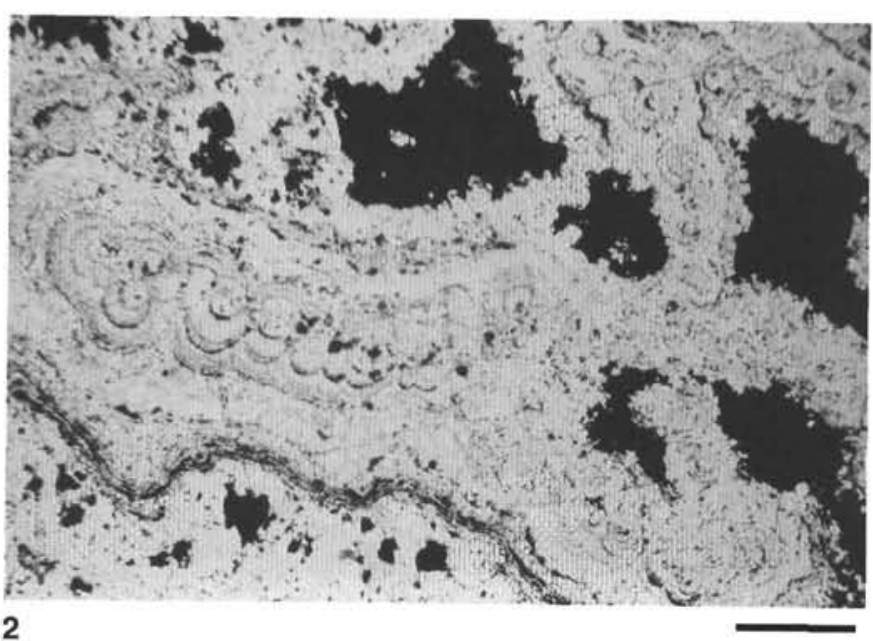

2

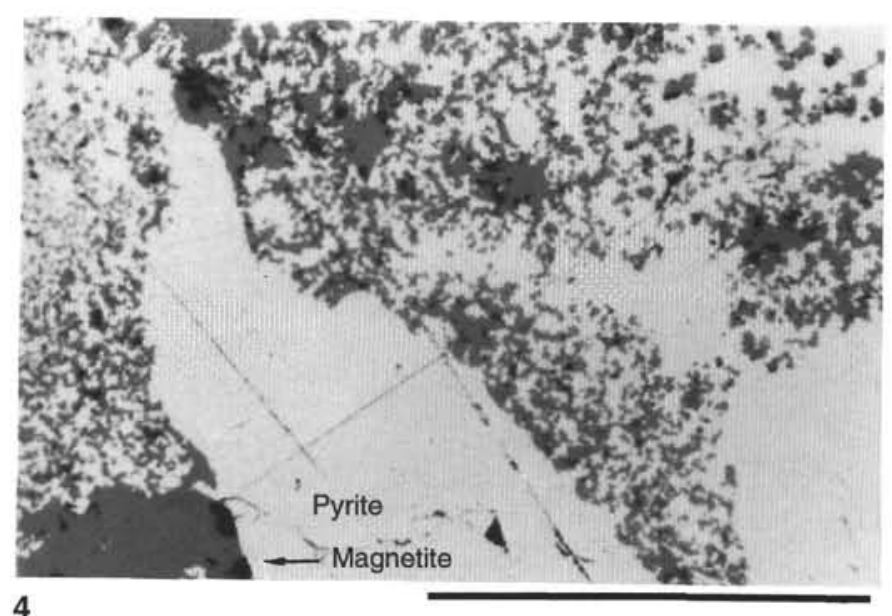

Plate 2. 1. SEM photomicrograph showing the alteration of pyrrhotite extending from cracks and grain boundaries. 2. Reflected-light photomicrograph showing typical colloform pyrite and associated porosity (dark spaces). Scale bar $=500 \mu \mathrm{m}$. 3. SEM photomicrograph of the "holey" pyrite that resulted from the oxidative dissolution of pyrrhotite. Some of the pore spaces are infilled with $\mathrm{Fe}, \mathrm{Mg}, \mathrm{Al}$ silicates. 4. Reflected-light photomicrograph showing pyrite-magnetite emulsion texture. Scale bar $=500 \mu \mathrm{m}$. 


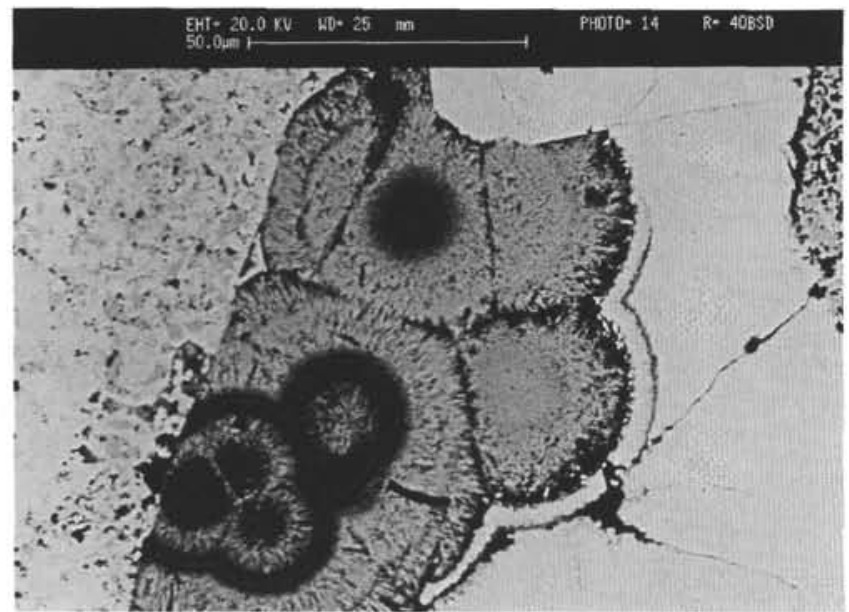

1

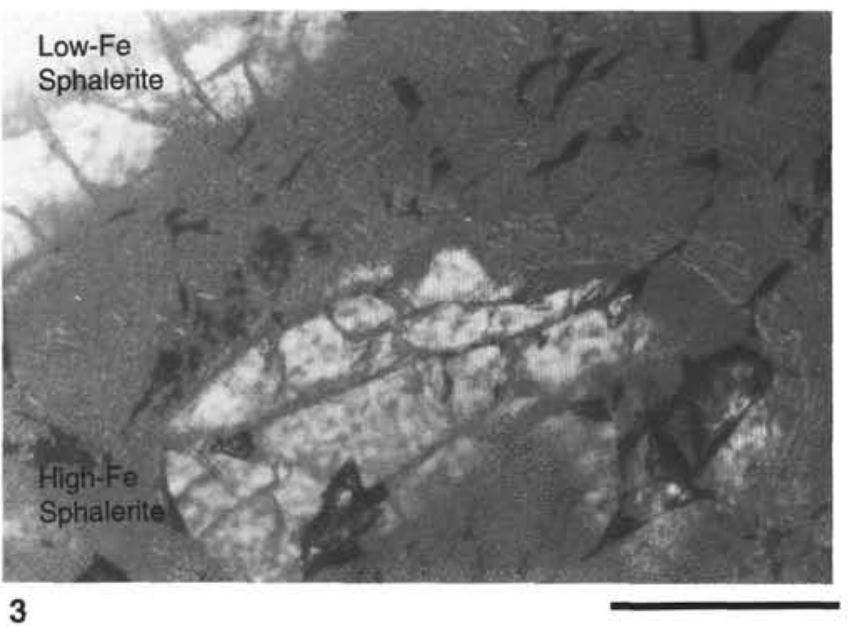

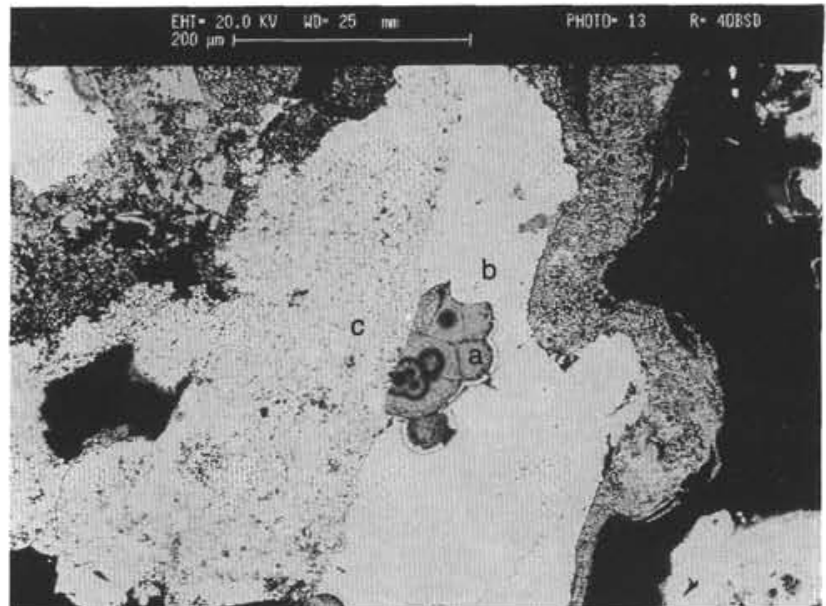

2

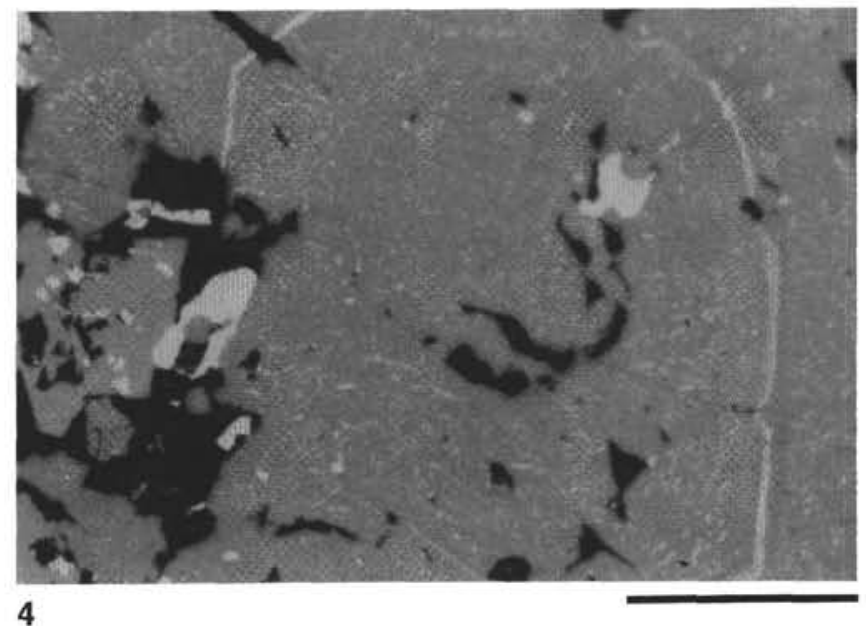

4

Plate 3. 1. SEM photomicrograph showing spheroidal structures composed of radially oriented magnetite fibers. Dark spaces are iron oxyhydroxides resulting from further oxidation; the top spheroid is being replaced by pyrite. The spheroidal structures may be pseudomorphs of marcasite, which commonly form such structures. 2. Low magnification SEM photomicrograph of Figure 1 showing multiphase replacement history of Fe-sulfides by Fe-oxides resulting from oxidation reactions. $\mathrm{a}=$ magnetite, $\mathrm{b}=$ pyrite, $\mathrm{c}=$ pyrite-magnetite emulsion; see text for discussion. 3. Photomicrograph taken in combined reflected and transmitted light showing the relationship between the iron zonation in the host sphalerite grain and zones of chalcopyrite. Scale bar $=500 \mu \mathrm{m}$. 4. Zoning of chalcopyrite around original zinc sulfide grain boundaries. Scale bar $=500 \mu \mathrm{m}$. 

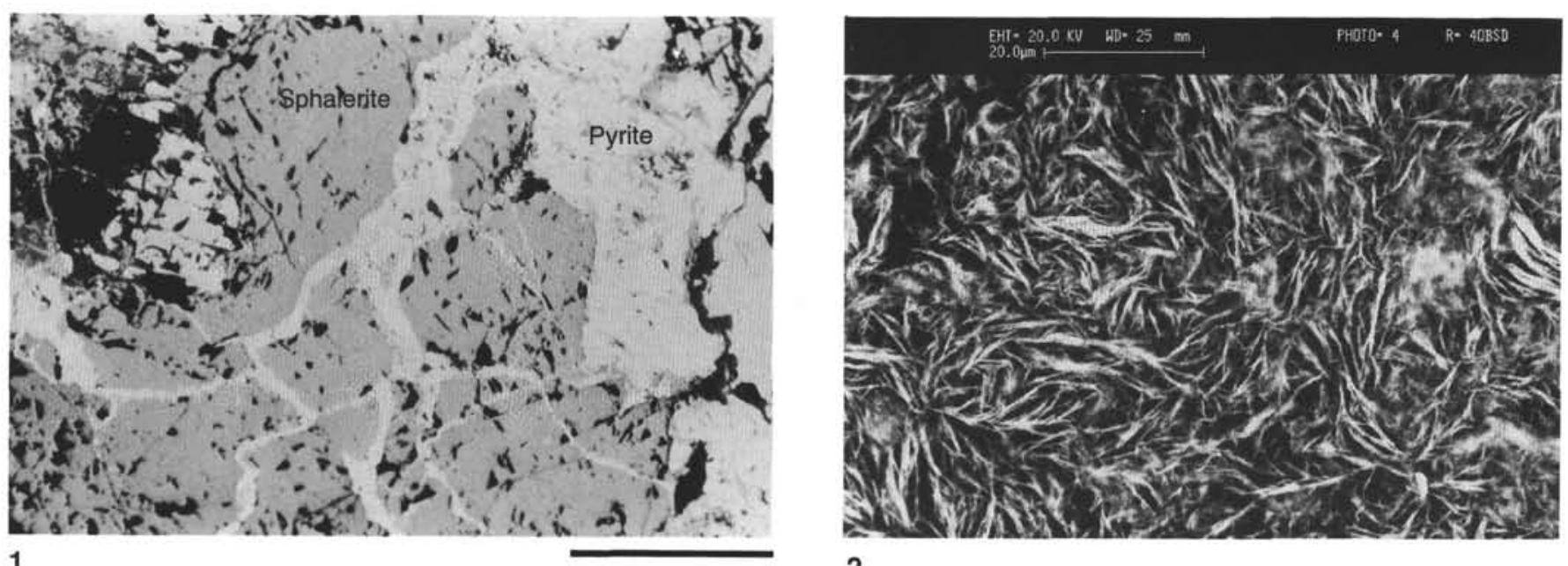

1

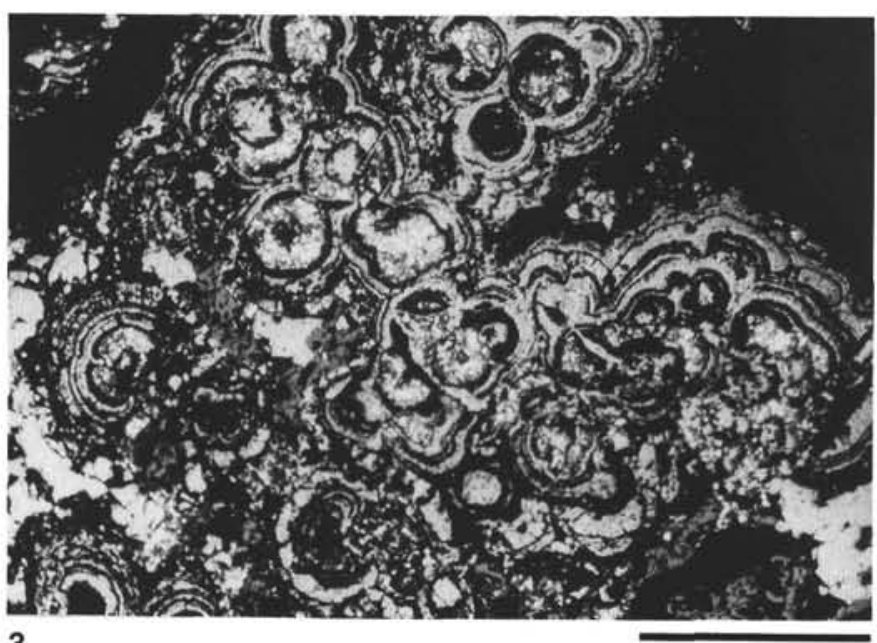

3
2

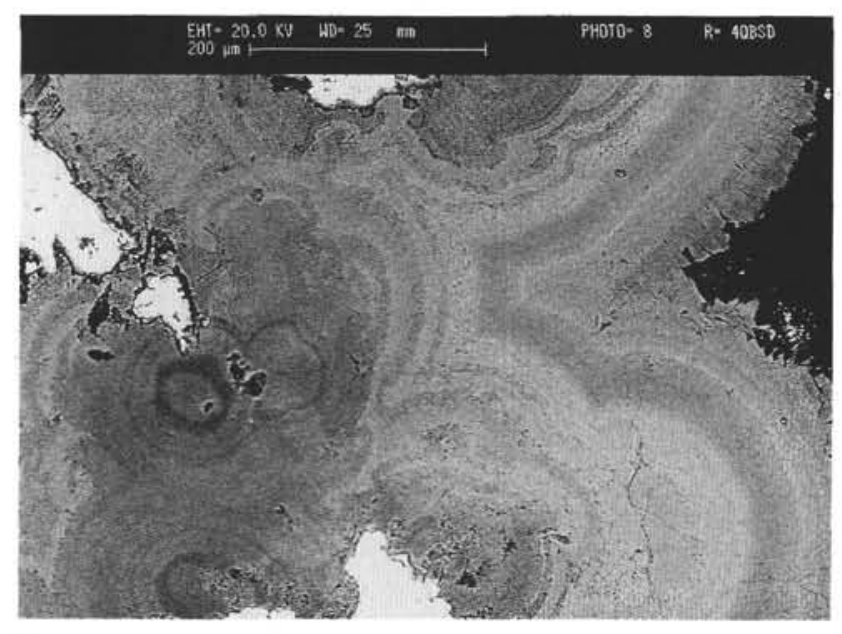

4

Plate 4. 1. Reflected-light photomicrograph of sphalerite crosscut and replaced by later pyrite. Scale bar $=500 \mu$ m. 2. SEM photomicrograph showing the fibrous nature of interstitial talc. 3. Reflected/transmitted-light photomicrograph of colloform pyrite structures, with the cores infilled by later magnesium silicates. Scale bar $=500 \mu \mathrm{m}$. 4. SEM photomicrograph showing colloform texture of $\mathrm{Mg}, \mathrm{Fe}, \mathrm{Ca}$ carbonates. Darker zones are more iron rich. 


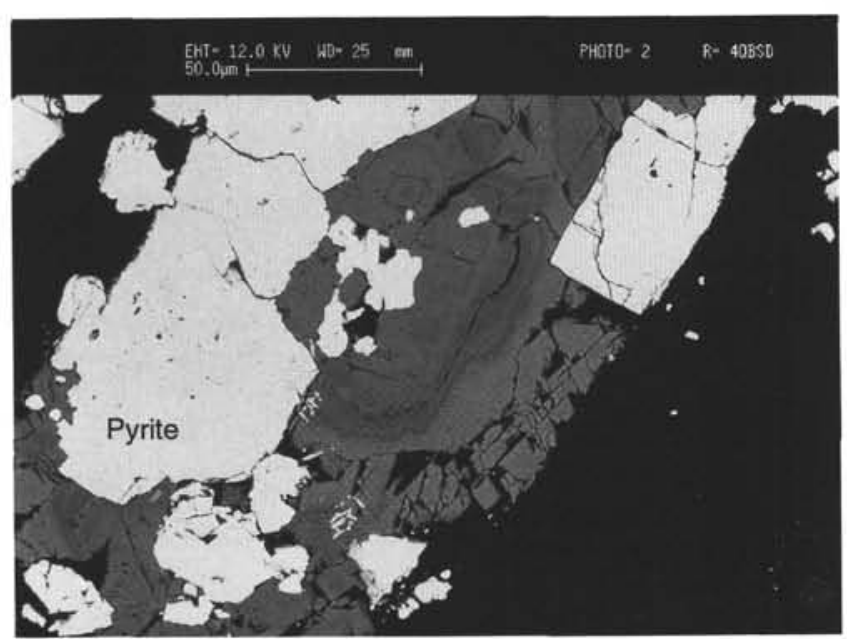

1

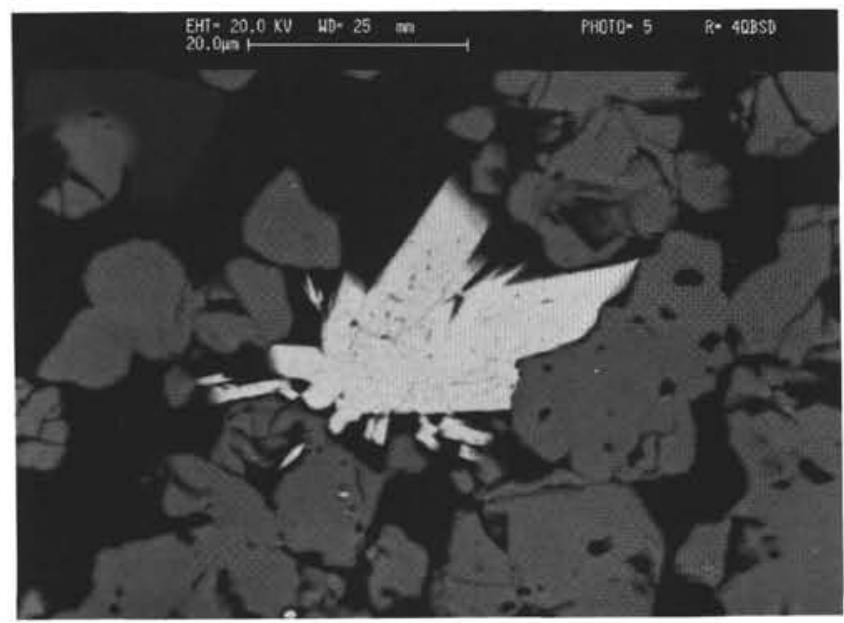

3

Plate 5. 1. SEM photomicrograph showing sharply defined zonations within carbonate grains. Darker zones are richer in magnesium relative to the lighter zones. Bright phase is pyrite and solid dark areas are voids. 2. SEM photomicrograph of barite crystals in pyrite. 3. SEM image of cassiterite (bright) associated with low-iron sphalerite (medium gray). Solid dark areas are holes.

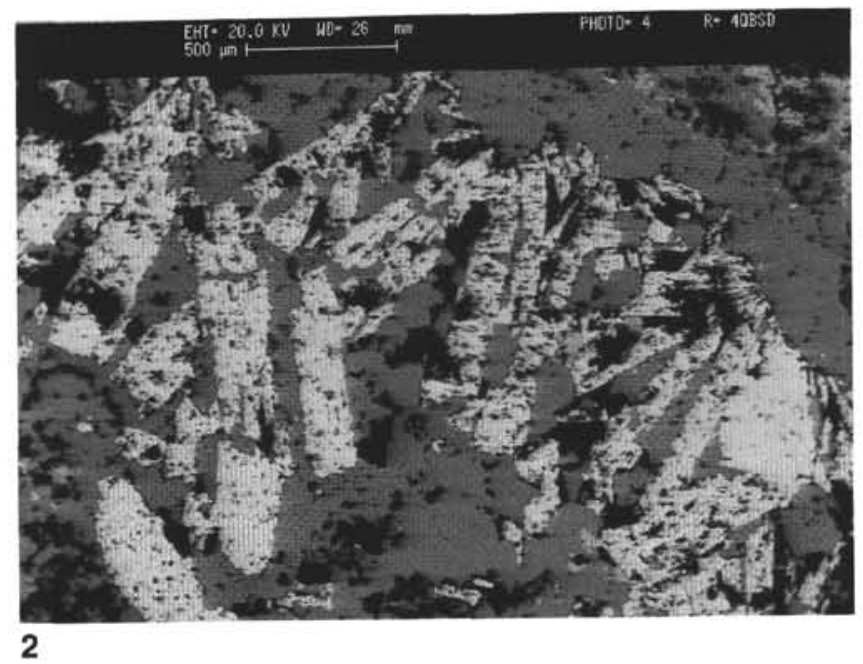

